OPEN ACCESS

Edited by:

Lars Rogge,

Institut Pasteur, France

Reviewed by:

Stanislas Goriely,

Université libre de Bruxelles, Belgium

Judith Smith,

University of Wisconsin-Madison,

United States

*Correspondence:

Mohamed Mandour

m.a.f.m.m.mandour@

amsterdamumc.nl

Specialty section:

This article was submitted to

Cytokines and Soluble

Mediators in Immunity,

a section of the journal

Frontiers in Immunology

Received: 17 October 2020

Accepted: 31 May 2021

Published: 29 June 2021

Citation:

Mandour M, Chen S and van de Sande MGH (2021) The Role

of the IL-23/L-17 Axis in Disease Initiation in Spondyloarthritis: Lessons

Learned From Animal Models.

Front. Immunol. 12:618581.

doi: 10.3389/fimmu.2021.618581

\section{The Role of the IL-23/IL-17 Axis in Disease Initiation in Spondyloarthritis: Lessons Learned From Animal Models}

\author{
Mohamed Mandour ${ }^{1,2^{*}}$, Sijia Chen ${ }^{1,2,3}$ and Marleen G. H. van de Sande ${ }^{1,2}$ \\ ${ }^{1}$ Department of Clinical Immunology and Rheumatology, Amsterdam Rheumatology \& Immunology Center (ARC), \\ Amsterdam University Medical Centers, Location Academic Medical Center, University of Amsterdam, Amsterdam, \\ Netherlands, ${ }^{2}$ Department of Experimental Immunology, Infection and Immunity Institute, Amsterdam University Medical \\ Centers, Location AMC, University of Amsterdam, Amsterdam, Netherlands, ${ }^{3}$ Division of Rheumatology, Inflammation, and \\ Immunity, Brigham and Women's Hospital and Harvard Medical School, Boston, MA, United States
}

Spondyloarthritis $(\mathrm{SpA})$ is a spectrum of chronic inflammatory joint diseases that frequently presents with inflammation of the axial skeleton, peripheral joints, entheses, skin, and gut. Understanding SpA pathogenesis has been proven challenging due to the limited availability of human target tissues. In recent years, the interleukin (IL)-23/IL-17 pathway has been implicated in the pathogenesis of SpA, in addition to the Tumor Necrosis Factor Alpha (TNF- $\alpha$ ) cytokine. The underlying molecular mechanisms by which the IL-23/IL-17 pathway triggers disease initiation, both in the joints as well as at extra-musculoskeletal sites, are not precisely known. Animal models that resemble pathological features of human SpA have provided possibilities for in-depth molecular analyses of target tissues during various phases of the disease, including the pre-clinical initiation phase of the disease before arthritis and spondylitis are clinically present. Herein, we summarize recent insights gained in SpA animal models on the role of the IL-23/IL-17 pathway in immune activation across affected sites in SpA, which include the joint, entheses, gut and skin. We discuss how local activation of the IL-23/IL-17 axis may contribute to the development of tissue inflammation and the onset of clinically manifest SpA. The overall aim is to provide the reader with an overview of how the IL-23/IL-17 axis could contribute to the onset of SpA pathogenesis. We discuss how insights from animal studies into the initiation phase of disease could instruct validation studies in at-risk individuals and thereby provide a perspective for potential future preventive treatment.

Keywords: spondyloarthritis, interleukin-23/IL-17 axis, HLA-B27, animal models, psoriatic arthritis 


\section{INTRODUCTION}

Spondyloarthritis $(\mathrm{SpA})$ is a chronic inflammatory joint disease characterized by inflammation and new bone formation which results in structural damage. Clinically, patients present with axial manifestations, such as sacroiliitis or spondylitis, and/or peripheral manifestations such as arthritis, dactylitis, or enthesitis. Besides, extra-musculoskeletal features, including psoriasis, inflammatory bowel disease, and uveitis, can be present (1). SpA comprises 2 subtypes: peripheral SpA, with psoriatic arthritis (PsA) as the prototypical disease, and axial $\mathrm{SpA}$, which encompasses radiographic axSpA, in which patients have signs of sacroiliitis on X-ray and fulfill the modified New York criteria (2), and the non-radiographic type (3). The disease pathogenesis of SpA is incompletely understood. Genetic factors combined with exposure to microbes by the loss of barrier function in the skin or the gut, or local mechanical stress at entheseal sites, are suggested to induce an inflammatory cascade resulting in joint inflammation and new bone formation. HLA-B27 is the strongest genetic factor linked to SpA. Genetic association studies, animal studies, human ex-vivo and intervention studies have demonstrated that the tumor necrosis factor alpha (TNF- $\alpha$ ) and interleukin (IL)-23/IL-17 pathways are key players in the inflammatory cascade, both in the initiation phase of $\mathrm{SpA}$, and during chronic persistent disease (4-6) (Figure 1).

TNF- $\alpha$ is a pleiotropic, pro-inflammatory cytokine playing major roles in protection against infections and driving inflammation in immune mediated inflammatory diseases including SpA. It is produced by various immune (activated T cells, macrophages, monocytes, neutrophils) and non-immune cells (fibroblasts, endothelial cells) (7). TNF- $\alpha$ is produced as a transmembrane bound protein expressed on the cell surface of various cell types including lymphocytes and macrophages, which is cleaved into a soluble form by metalloprotease TNF- $\alpha$ converting enzyme (TACE), also called A Disintegrin and Metalloprotease 17 (ADAM17). Both the transmembrane and soluble forms of TNF- $\alpha$ are biologically active and can bind to the TNF- $\alpha$ receptors 1 and 2, but their downstream effects vary $(8,9)$.

IL-17A is a pro-inflammatory cytokine implicated in various inflammatory disorders. IL-17A by itself only has a modest proinflammatory effect but acts as a potent enhancer of inflammation through synergy with other proinflammatory cytokines such as TNF- $\alpha$ (10). IL-17A was the first to be characterized among the 6 conserved IL-17 proteins (IL-17A-F),

\footnotetext{
Abbreviations: ADAM17, A disintegrin and metalloprotease 17; AIA, adjuvantinduced arthritis; AxSpA, Axial spondyloarthritis; CIA, collagen-induced arthritis; DCs, Dendritic cells; HLA-B27/Huß2m- tg, HLA-B27/human $\beta 2$ microglobulin transgenic rat; IL-23R, Interleukin 23 receptor; IL-23, Interleukin 23; IL-17A, Interleukin 17A; ILC, Innate lymphoid cells; LN, Lymph node; MLN, Mesenteric lymph node; NF- $\kappa B$, Nuclear factor kappa-Beta; PsA, Psoriatic arthritis; NSAIDs, Non-steroidal anti-inflammatory drugs; PLN, Popliteal lymph node; PRR, Pattern recognition receptors; PsO, Psoriasis; TACE, TNF- $\alpha$ converting enzyme; TLR, Toll like receptors; TNF- $\alpha$, Tumour necrosis factor alpha; TNFR1, Tumor necrosis factor receptor 1; TTP, Tristetraprolin; RANKL, Receptor activator of nuclear factor кB ligand; STAT3, Signal transducer and activator of transcription 3; SpA, Spondyloarthritidis; SPF, Specific pathogen free; UPR, Unfolded protein response.
}

followed by IL-17F, which is for $50 \%$ structurally similar to IL-17A $(11,12)$. The IL-17 receptor family comprises the subunits IL-17RA, IL-17RB, IL-17RC, IL-17RD, and IL-17RE. After binding of IL-17A or F to their receptors, Act1 associates with the IL-17 receptor resulting in the activation of various downstream signaling pathways (13). IL-23 is the canonical cytokine that activates IL-17A production. It is a heterodimeric cytokine, which contains a P19 and a P40 subunit. The P19 unit is exclusive to IL-23 whereas the P40 subunit is shared with IL-12 (14). IL-23 signals through the IL-23R and IL-12ß1 subunits resulting in activation of the JAK-STAT pathway mainly via STAT3 (15). More recently, it has been shown that T cells and innate (-like) lymphocytes can produce IL-17A in response to cytokines other than canonical IL-23. These alternative cytokines include IL-7 and IL-9, which classically are required to maintain peripheral innate(-like) $\mathrm{T}$ cell populations (16-18). Other diverse innate immune cells also produce IL-17, including $\gamma \delta \mathrm{T}$ cells, NKp46+ NK cells, intestinal Paneth cells, invariant natural killer T cells (iNKT), MAIT cells and neutrophils (19). The emergence of distinct pathways culminating in the secretion of IL-17A, in addition to the canonical IL-23/IL-17 pathway, underscores the importance of IL-17A in human health and disease (20). In SpA, IL-17A driven inflammation contributes to erosive joint damage and pathological new bone formation (21).

Although the IL-23/IL-17 axis has a central role in SpA pathology, antibodies targeting IL-17A and IL-23 have demonstrated different levels of efficacy in the various subtypes of SpA (22-24). Most strikingly, IL-23 inhibition in human radiographic axSpA patients was not effective (25), whereas IL17A-blocking therapies decreased inflammation and disease severity $(6,26)$. These clinical findings are supported by findings in the Mycobacterium tuberculosis (M.tb) accelerated HLA-B27 transgenic rat (27) model. The disease phenotype in this model resembles human SpA as these rats develop signs of arthritis and spondylitis, with inflammation and new bone formation. When IL-23 inhibition was started after the rats had developed established disease with arthritis and spondylitis, there was a lack of efficacy just as observed in patients $(25,28)$. In contrast, blocking IL-23R just after immunizing the rats completely prevented inflammation and new bone formation (24). These findings suggest that it may be necessary to block IL-23 in the pre-clinical phase, before the disease phenotype becomes clinically apparent. Based on these findings in the rats, it could be hypothesized that there may be a pre-clinical disease stage also in human SpA where specific immune pathways are already activated before the disease becomes clinically manifest (Figure 1). This concept of a preclinical "at-risk phase" phase is already well-established in a different form of chronic arthritis, rheumatoid arthritis (RA) (29-31). Better understanding of the molecular alterations present in the at-risk phase of RA have resulted in initial treatment trials aiming to prevent onset of disease $(32,33)$.

For long, it has been speculated that extra-musculoskeletal tissue inflammation in SpA contributes to the initiation of arthritis and spondylitis and subsequent development of full-blown SpA. To address the potential tissue-specific role of IL-23/IL-17 in both joint and extra-musculoskeletal tissues, it would be ideal to 


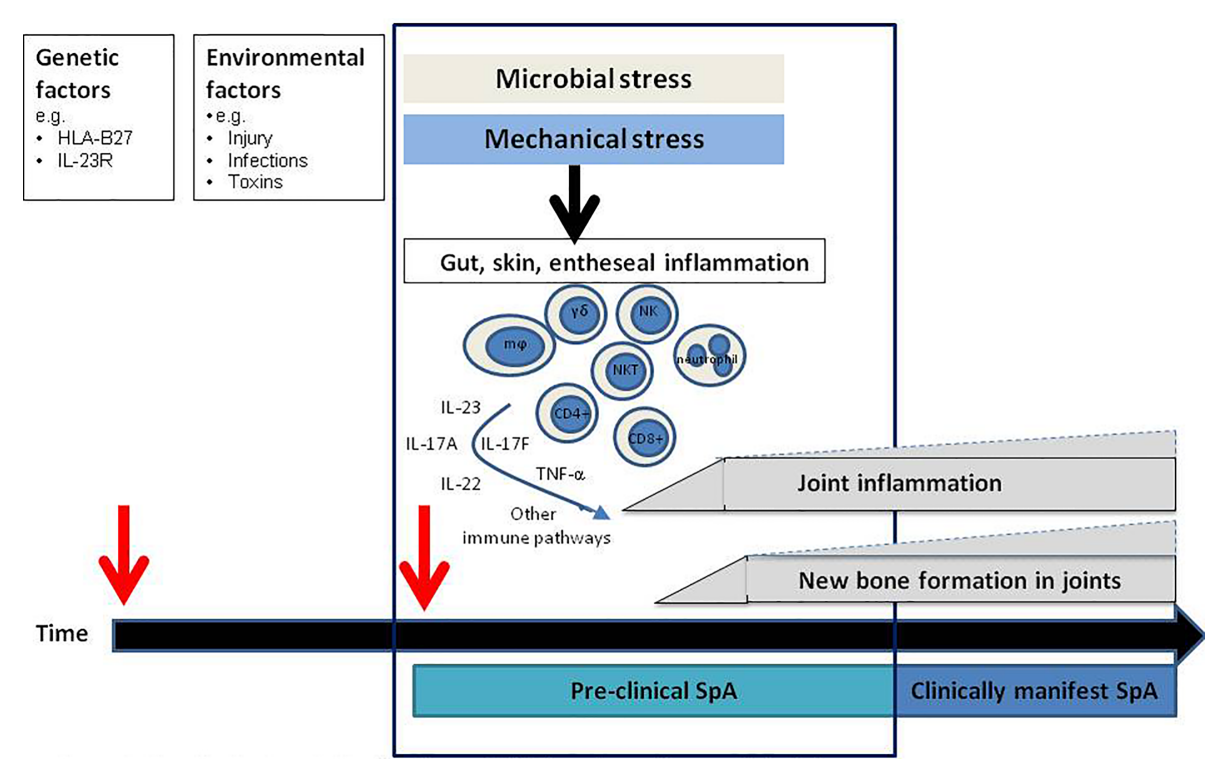

FIGURE 1 | Hypothetical model for the disease initiation phase: the pre-clinical phase. In the pre-clinical phase of disease innate immune triggering results in activation of specific pathogenic immune pathways site distant from the joints resulting in (subclinical) joint inflammation and new bone formation which subsequently develops into clinically manifest spondyloarthritis (SpA). m申, macrophages, NK, NK cells; NKT, NKT cells; $\gamma \delta$, gamma delta T cells.

examine these target tissues, however, this is challenging due to the relative lack of tissue samples that can easily be obtained from affected lesions. This is even more challenging in individuals who are at increased risk of SpA, before the onset of clinically manifest disease. Animal data could provide a good basis for future human studies allowing better understanding of the disease development, and on how extra-musculoskeletal tissues are involved in initiation of this disease. Increased understanding of the molecular pathways active in this very early stage of disease in SpA might identify novel potential treatment targets or even provide a basis for preventive treatment strategies aiming to further improve outcome for SpA patients.

Here, we provide an overview of findings from various experimental SpA animal models indicating how the IL-23/IL17 axis is implicated in the initiation and progression of disease, with a focus on the major tissues involved in SpA pathogenesis.

\section{EXPERIMENTAL MODELS OF SPA}

Evidence from studies in animal models, human expression studies, and SpA genetic association studies, has indicated that the IL-23/IL17-axis contributes to pathogenesis of chronic arthritis, spondylitis, and associated inflammatory manifestations (34).

There are several animal models that bear resemblance to human SpA (Figure 2) (35-37). These models differ in genetic modifications, disease mechanism and pathologic features. Collectively, they contribute to dissecting the pathogenic processes in SpA disease development and progression. Herein, we first briefly summarize the most commonly used experimental models of SpA. An thorough overview of these SpA animal models has been previously presented by Viera de Sousa et al. (35). There are more recent animal models developed since, which we are highlighting here as well (37).

\section{HLA-B27/Huß2m Overexpression}

HLA-B27 is the major genetic risk factor for $\operatorname{SpA}(38,39)$, and overexpression of HLA-B27 resulted in clear SpA-like features in rats (38), but not in mice (40). Over time, the HLA-B27 transgenic (tg) rat model has progressed from the HLA-B27/ human $\beta 2$ microglobulin $(\mathrm{h} \beta 2 \mathrm{~m})$ (tg) Lewis $(21-4 \mathrm{H})$ rats, characterized by orchitis, colitis and hind limbs arthritis, with psoriasis in up to $50 \%$ of the rats, to the HLA-B27/h $\beta 2 \mathrm{~m}$ - tg F344 (33-3) rats with similar clinical manifestations but with earlier disease onset. This was followed by the HLA-B27/h $\beta 2 \mathrm{~m}$-tg Lewis rats (21-3 x 283-2)F1 line with lower HLA-B27 copy numbers, in which all male rats develop orchitis, followed by the development of arthritis (4-6 months age) in $70 \%$ of all male rats, and spondylitis (7-9 months age) in $50 \%$ of them (41). These rats also show signs of peripheral and axial new bone formation. Most recently, immunizing the (21-3 x 283-2)F1 rats with heatinactivated Mycobacterium tuberculosis (M.tb) has been demonstrated to synchronize and accelerate the disease onset in both male and female rats. Arthritis and spondylitis development is visible in $80-100 \%$ of the rats $2-3$ weeks post M.tb immunization (35).

\section{TNF- $\alpha$ Overexpression}

TNF- $\alpha$ is one of the key cytokines in SpA pathogenesis and there are several animal models that are based on TNF- $\alpha$ overexpression. 


\begin{tabular}{|c|c|c|c|c|c|c|c|c|c|c|}
\hline & & arthritis & spondylitis & enthesitis & colitis & psoriasis & uveitis & $\begin{array}{l}\text { new bone } \\
\text { formation }\end{array}$ & bone loss & other \\
\hline & $\begin{array}{l}\text { HLA-B27/Huf2m-tg } \\
\text { Levis rats }(21-4 H)\end{array}$ & $x$ & $\mathrm{x}$ & $\mathrm{x}$ & $x$ & $x$ & $x$ & $x$ & $x$ & $\begin{array}{c}\text { dactylitis, } \\
\text { epididymoorchit is }\end{array}$ \\
\hline \multirow{3}{*}{$\begin{array}{c}\text { HLA-B27/Huß2m } \\
\text { overexpression }\end{array}$} & $\begin{array}{l}\text { HLA-B27/HufFm-tg F344 } \\
\text { rats (33-3) }\end{array}$ & $x$ & & $\bar{x}$ & $\mathrm{x}$ & $x$ & & $\mathrm{x}$ & $\mathrm{x}$ & $\begin{array}{c}\text { dactylitis, } \\
\text { epididymoorchitis }\end{array}$ \\
\hline & $\begin{array}{l}\text { HLA-B27 Huß2m-tg Levis } \\
\text { rats }(21-3 \times 282-2) \text { F1 }\end{array}$ & $x$ & $x$ & & & $\mathrm{x}$ & & $x$ & $x$ & $\begin{array}{c}\text { dactylitis, } \\
\text { epididymoorchitis }\end{array}$ \\
\hline & $\begin{array}{l}\text { Heat inactivated } M \text { tb } \\
\text { induced HLA-B27 Huß2m tg } \\
\text { Levis rats }(21-3 \times 283-2) F 1\end{array}$ & $\mathrm{x}$ & $x$ & & & & & $x$ & $x$ & $\begin{array}{c}\text { vactylitis, } \\
\text { epididymoorchitis }\end{array}$ \\
\hline
\end{tabular}

\begin{tabular}{|c|c|c|c|c|c|c|c|c|c|c|}
\hline & & arthritis & spondylitis & enthesitis & colitis & \begin{tabular}{|l} 
psoriasis \\
\end{tabular} & uveitis & \begin{tabular}{|l|} 
new bone \\
formation
\end{tabular} & bone loss & other \\
\hline \multirow{3}{*}{$\begin{array}{c}\text { TNF- } \alpha \\
\text { overexpression }\end{array}$} & TNF $\triangle A R E$ mice & $x$ & & $\mathrm{x}$ & $x$ & & & & $x$ & \\
\hline & $\begin{array}{l}\text { Transmembrane TNF } \\
\text { tg mice (TgA86) }\end{array}$ & $x$ & $\mathrm{x}$ & $\mathrm{x}$ & & & & $\mathrm{x}$ & $x$ & \\
\hline & $\begin{array}{l}\text { Human TNF tg mice } \\
\text { (Tg197) }\end{array}$ & $x$ & & & & & & & $\mathrm{x}$ & weight loss \\
\hline
\end{tabular}

\begin{tabular}{|c|c|c|c|c|c|c|c|c|c|c|}
\hline & & arthritis & spondylitis & enthesitis & colitis & psoriasis & uveitis & $\begin{array}{l}\text { new bone } \\
\text { formation }\end{array}$ & bone loss & other \\
\hline \multirow{4}{*}{$\begin{array}{l}\text { IL-23/IL-17 } \\
\text { related }\end{array}$} & $\begin{array}{l}\text { IL-23mc induced B10.RIII } \\
\text { mice }\end{array}$ & $\begin{array}{l}x \\
x\end{array}$ & $x$ & $\mathrm{x}$ & $\mathrm{x}$ & $\mathrm{x}$ & & $x$ & $\mathrm{x}$ & \\
\hline & $\begin{array}{l}\text { R26STAT3CHootili CD4Cre } \\
\text { mice }\end{array}$ & $\mathrm{x}$ & & $\mathrm{x}$ & & $\mathrm{x}$ & & & $x$ & \\
\hline & K5.Stat3C:F759 mice & $x$ & & & & $x$ & & & & \\
\hline & $\begin{array}{l}\text { Curclan- induced SKG } \\
\text { mice }\end{array}$ & $\mathrm{x}$ & $x$ & & $\mathrm{x}$ & & & $x$ & $x$ & $\begin{array}{l}\text { veight loos, } \\
\text { uveitis, dactylitis }\end{array}$ \\
\hline
\end{tabular}

\begin{tabular}{|c|c|c|c|c|c|c|c|c|c|c|}
\hline & & arthritis & spondylitis & enthesitis & colitis & psoriasis & uveitis & $\begin{array}{l}\text { new bone } \\
\text { formation }\end{array}$ & $\begin{array}{l}\text { bone } \\
\text { loss }\end{array}$ & other \\
\hline \multirow[t]{3}{*}{ Othermodels } & $\begin{array}{l}\text { Aging male DBA } / 1 \\
\text { mice }\end{array}$ & $x$ & & $x$ & & $x$ & & $x$ & & \\
\hline & $\begin{array}{l}\text { IL27RA } A^{-\%} p 53^{R .172 H / 4} \\
\text { mice }\end{array}$ & & $x$ & & & & & $x$ & $x$ & \\
\hline & $\begin{array}{l}\text { Tristetraprolin (TTP) } \\
\text { KO mice }\end{array}$ & $x$ & & $x$ & & $x$ & & & & cachexia \\
\hline
\end{tabular}

FIGURE 2 | Animal models resembling human spondyloarthritis. HLA-B27/Huß2m- tg, HLA-B27/human $\beta 2$ microglobulin transgenic rat; TNF- $\alpha$, Tumor necrosis factor alpha; IL-23, Interleukin-23; IL-17, Interleukin-17; M. tub, Mycobacterium tuberculosis; IL-23mc, Interleukin-23 minicircle; Human TNF tg mice, Human tumor necrosis factor transgenic mice.

In the $\mathrm{TNF}^{\triangle \mathrm{ARE}}$ mice, the overexpression of murine TNF- $\alpha$ leads to chronic peripheral polyarticular synovitis, enthesitis and colitis, without psoriasis, osteoproliferation or spinal involvement (4244). The colitis severity varies from asymptomatic histological inflammation to severe ileitis depending on housing conditions. In contrast, mice that overexpress transmembrane TNF (tmTNF) (TgA86) (45) do develop new bone formation together with signs of peripheral arthritis and spondylitis, without gut or skin involvement (35). The human TNF-(Tg197) tg mice is a model characterized by destructive polyarticular synovitis (including sacroiliitis), with no spinal involvement, new bone formation, gut or skin inflammation (46). The differences in clinical presentation between the soluble and tmTNF overexpression models indicate that tmTNF drives the key clinical phenotype and pathologic bone formation of SpA.

\section{IL-23/IL-17 RELATED ANIMAL MODELS OF SPA}

Animal models played an important role in implicating the IL23/IL-17 axis in SpA pathogenesis. In the IL-23 minicircle (mc) induced B10.RIII mice model, high systemic IL-23 expression results in axial and peripheral enthesitis with entheseal new bone formation, with no destructive synovitis at day 35 (47). Another model that is considered IL-23/IL-17 dependent is the SKG model with the ZAP-70 ${ }^{\mathrm{W} 163 \mathrm{C}}$ mutation. This ZAP-70 ${ }^{\mathrm{W} 163 \mathrm{C}}$ mutation is downstream of the $\mathrm{T}$ cell receptor signaling complex. This mutation affects positive and negative selection of $\mathrm{T}$ cells. Moreover, it alters the generation and function of CD25+CD4+ natural regulatory $\mathrm{T}$ (Treg) cells (48). SKG mice develop arthritis, enthesitis, spondylitis, peripheral new bone formation and Crohn's disease-like ileitis, but without clear signs of axial new bone formation. The disease onset can be synchronized by one IP injection of the fungal wall component curdlan. In this model, curdlan activates IL-23 release, inducing mucosal dysregulation and IL-17 and IL-22 cytokine expression, driving the SpA phenotype $(49,50)$.

Recently, IL-27RA ${ }^{-/-}$p53 $3^{\mathrm{R} 172 \mathrm{H} /+}$ mice have been demonstrated to show SpA-like disease (37). As a result of knocking out IL-27RA, these mice lack the inhibitory effect of IL-27 on Th17 lineage differentiation. IL-27 is a member of the IL-12 cytokine family and is known to down regulate IL-23, RAR-related orphan receptor (ROR)- $\gamma \mathrm{t}$, and Th17 differentiation $(12,47,51)$, while p53 is known to negatively regulate osteoblast differentiation, bone formation and 
remodeling pathway (52). The $\mathrm{IL}-27 \mathrm{RA}^{-/-} \mathrm{p} 53^{\mathrm{R} 172 \mathrm{H} /+}$ mice demonstrate minimal axial inflammation and bone loss, with pathological bone formation at the intervertebral discs (37). Moreover, these mice also show skin inflammation (neutrophilic dermatitis) and additional organ pathology including chronic kidney nephropathy $(37,53)$.

Other models reflecting the importance of IL-17A production in SpA disease pathogenesis are the STAT3 overexpression models. STAT3 is a key regulatory factor inducing differentiation of naïve $\mathrm{CD}^{+} \mathrm{T}$ cells into Th17 cells (54). The group of Yang Lu introduced the R26STAT3C ${ }^{\text {stopfl/fl }}$ CD4Cre mouse model reflecting SpA with signs of psoriasis, driven by a specific hyperactive T cell-STAT3C allele $(55,56)$. The disease manifestations include spontaneous development of psoriatic skin lesions, enthesitis/tendinitis, and arthritis (57). Peri-articular bone erosion and osteopenia were also observed, without signs of new bone formation.

Similarly, overexpression of STAT3 in the K5.STAT3C:F759 murine model also results in spontaneous severe psoriatic cutaneous lesions and peripheral erosive arthritis (36).

\section{OTHER MODELS}

The aging male DBA/1 mice spontaneously develop brief arthritis, dactylitis, and enthesitis. In 10-12 weeks old mice progressive endochondral bone formation has been shown but still without axial or extra-articular pathologic changes $(58,59)$.

More recently, the Tristetraprolin (TTP) KO model has been shown to develop a severe, systemic inflammatory syndrome, with destructive arthritis, conjunctivitis, dermatitis, osteopenia, myeloid hyperplasia and cachexia (60). TTP is a RNA binding protein that has important endogenous anti-inflammatory effects, through destabilizing mRNAs encoding pro-inflammatory cytokines and suppressing their biosynthesis (e.g. TNF- $\alpha$ ). The clinical and immunological phenotype associated with TTP deficiency was dependent on the IL-23/IL-17A axis (61). Most of the expressed phenotype was prevented using anti- (TNF- $\alpha$ ) antibody treatment (60).

\section{INVOLVEMENT OF IL-23/IL-17 AXIS IN THE INITIATION PHASE OF DISEASE}

Although the major clinical presentation of SpA involves the joints (axial or peripheral), innate immune activation by either microbial stress caused by barrier dysfunction at the gut or the skin, or by mechanical stress caused by microtrauma at the entheses, is thought to trigger disease onset (27). The exact underlying mechanisms are not yet fully understood (Figure 2). To gain more insight into the disease initiation phase, of SpA, when first pathological molecular alterations occur, we assessed the result of IL-23 and IL-17 dysregulation in SpA experimental models. We highlight studies in which the disease initiation in SpA may be explained by IL-23/IL-17 activation systemically or locally in the entheseal areas close to the joints. Moreover, we will discuss other potential initiation sites of SpA by summarizing how gut and skin inflammation may relate to development of joint inflammation.

Sherlock et al. have shown that induction of high systemic IL-23 levels can induce enthesitis before development of new bone formation and synovial joint destruction. After induction of disease with IL-23mc, mice develop paw swelling at day 5-10 with entheseal inflammation (47). Although F4/80+ macrophages and myeloperoxidase (MPO)+ neutrophils were observed in the entheseal inflammatory infiltrate, IL-23 responsive $\mathrm{ROR} \gamma \mathrm{t}+\mathrm{CD} 3+\mathrm{CD} 4-\mathrm{CD} 8$ - entheseal resident $\mathrm{T}$ cells, later identified as $\gamma \delta$ T cells (62) were shown to be important for initiating inflammation, as this specific subset of $\mathrm{T}$ cells were shown to produce IL-17A and IL-17F, and IL-22 (47) and inhibition of IL-17 and/or IL-22 did decrease disease severity. Depletion of Th17 cells was shown not to change the disease course, indicating that indeed the resident entheseal T cells play an important role in driving the disease onset. In this model, the entheseal inflammation was followed by expansion of periosteal osteoblasts by day 18 , accompanied by a molecular new bone formation gene expression profile. Entheseal new bone formation was observed at day 35 (47).

In the SKG model, curdlan (consisting of the fungal wall component beta-glucan) signaling via the dectin 1 patternrecognition receptor, that specifically recognizes beta-glucans, was applied as a trigger of a SpA phenotype $(49,63)$. Curdlan injection induces ileal IL-23 secretion, which in turn provokes a state of mucosal dysregulation and cytokine imbalance. The mice develop (histological) inflammation at the axial and peripheral entheses 1 week after curdlan induction followed by development of clinical enthesitis, sacroiliitis, peripheral arthritis and colitis and uveitis with increased serum levels of IFN- $\gamma$, TNF- $\alpha$, IL- 6 and IL-17A. The surge of IFN- $\gamma$, IL- 6 and IL-17A cytokines was shown to be IL-23 dependent $(50,64)$. The disease manifestations were shown to be IL-23 dependent and partially IL-17 dependent (64). Early IL-23 inhibition using anti-IL-23 mAb before disease induction in SKG mice resulted in a clear clinical improvement in these mice. There were no histological signs of arthritis and spondylitis $(50,64)$.

The importance of IL-23 in disease initiation was also found in the accelerated heat-inactivated M.tb induced HLAB27 tg rat model. It was shown that there is a short increase in $I L-23 R$ expression and RORC gene expression shortly after immunization (24). Blocking IL-23R after immunization but before onset of clinical manifestations completely prevented arthritis and spondylitis development. This prophylactic treatment significantly suppressed the lymph nodes and splenic mRNA expression of various downstream cytokines, e.g. Il-17A, Il-22, Mmp3 and Ccl20. However, expression of other proinflammatory cytokines such as Il-17F, Ifn- $\gamma, \operatorname{Tnf}-\alpha$, and Il-6 were not affected by IL-23R blocking. Although IL-23 was clearly implicated in disease initiation, the source and the cell type(s) responsive to IL-23 in this model need to be elucidated (24).

In the same accelerated HLA-B27tg rat model, prophylactic anti-IL-17A treatment significantly delayed the development and decreased the severity of spondylitis and arthritis. On histology there was less inflammation and less destruction in axial and peripheral joints in anti-IL-17A treated rats, but the disease 
onset was not prevented (65). This is in contrast to the findings with anti-IL-23R blocking therapy, as anti-IL23R did prevent the disease onset.

Strikingly, in the B10.RII mice, the use of IL-17Amc DNA over-expression, as well as IL-17A blockade revealed no major role for IL-17A in driving arthritis in the B10.RIII model (47). Consistent with that, IL-17A deficiency in the IL-17A ${ }^{-/-}$SKG mice only resulted in a moderate reduction of the SKG phenotype (64). Altogether, the data from these SpA models indicate that IL-17A is likely not the only cytokine that contributes to the initiation of IL-23 dependent arthritis.

In addition to IL-17A, IL-22, as a downstream cytokine of IL23, was shown to be relevant for the severity of enthesitis in both the IL-23mc and SKG mice model $(47,64,66)$. Ex vivo gene expression profiling revealed the induction of murine $\mathrm{Il}-6, \mathrm{Il}-22$ and Cxcl1 by day 5 of IL-23 expression in the IL23mc model (47). Blocking IL-22 in SKG mice for 8 weeks from the first moment of clinical manifestations reduced Achilles tendon enthesitis, similar to the reduced severity of enthesitis observed in the IL$17 \mathrm{~A}^{-/-}$SKG mice (64).

The aforementioned animal studies link IL-23 responsive cells to initiation of disease and development of clinical SpA manifestations. In humans innate immune cells have been reported to express IL-23R with inducible IL-17A/F expression (67). Recently also presence of conventional CD4+ and CD8+ T cells have been reported in human entheses, which upon stimulation could produce TNF- $\alpha$ and IL-17A. However, IL-17 production here is independent of IL-23 (67-69). If these cells could play a role in the onset of SpA in humans needs further investigation. This link between IL-23 responsive cells and initiation of disease in animal models direct further in depth characterization of both innate and adaptive immune cells from the moment of triggering of inflammation (possibly in the preclinical disease stage) to onset of clinically manifest spondyloarthritis to further elucidate which IL-23 responsive cells drive pro-inflammatory cytokine production, including IL-17A, and which cells drive IL-17 production independently of IL-23.

Altogether, IL-23 plays an important role in inducing SpA pathology as revealed in the different models. If immune dysregulation of IL-23 is also present in the pre-clincal phase of human SpA needs further investigation. If in the future we can identify individuals at very high risk of developing SpA, who would qualify for preventive treatment strategies, then anti-IL23 treatment could be suggested to be the first candidate to be tested as a preventive medicine. However, currently we lack good predictive tools that could identify those individuals at increased risk of developing SpA who would qualify for such a treatment strategy.

\section{THE GUT-JOINT AXIS IN THE INITIATION OF SPONDYLOARTHRITIS}

SpA patients often present with gut inflammation which led to the hypothesis that inflammation at the gut mucosa may initiate SpA pathogenesis $(70,71)$. Theoretically, gut inflammation could result in loss of intestinal barrier integrity allowing microbes and dietary antigens to enter into the bloodstream, and trigger immune dysregulation leading to joint inflammation (72-74). An in-depth review discussing the gut-joint axis in SpA was recently provided by Gracey et al. (71). Here we will discuss current literature on the potential crucial role of the IL-23/IL-17 axis in the transition of inflammation from the gut to the joint.

IL-17 has been considered to play a dual role in gut homeostasis. Whereas IL-23-independent IL-17A production by innate(-like) immune cells is considered to be protective in colitis by maintaining barrier function in the intestines $(75,76)$, IL-23-dependent IL-17A production by Th17 cells results in gut inflammation $(76,77)$. This might explain the opposing effects observed in clinical trial in active crohn's disease where IL-17A inhibition resulted in worsening of colitis, but treatment with anti-IL-12/IL-23p40 as well as p19 inhibition (78) improved inflammation (79). In addition to IL-17A, IL-17F has been demonstrated to promote inflammation in the intestines through its effect on the intestinal microbiome in mice (80). A study in experimental colitis provided evidence that inhibition of both IL-17A and IL-17F was necessary to attenuate colitis (81). IL-22 is another key player in intestinal host defense and maintaining mucosal homeostasis, which adds further complexity to role of the IL-17/IL-23 axis in gut inflammation. It induces direct intestinal expression of complement C3 and mucin genes, shares in the clearance of pathogens (82-84), via facilitating the production of cytokines and chemokines that mediate innate cell recruitment to infection sites (84). Furthermore, IL-22 has been shown to regulate hemopexin production, in order to impair bacterial growth (85).

Gut inflammation is a prominent feature in the high copy numbers HLA-B27 tg rat models (21-4H and 33-3 line) (38). Colitis is seen at 6 weeks age and increased Il-23p19 expression occurred at the start of colitis associated with increased $I l-17 \mathrm{~A}$, next to Il-1, Il-6, and Tnf- $\alpha$ expression. IL-23p19 and IL-17A transcripts were localized to CD11c+ antigen presenting cells and CD4+ T cells, respectively (86). This was accompanied by increased HLA-B27 expression and signs of HLA-B27 misfolding with an unfolded protein response (86). Mechanistically, it is thought that the increased HLA-B27 expression in activated macrophages results in an unfolded protein response with ER stress promoting IL-23 expression (86-88). This IL-23 could then induce pathogenic IL-17A production by Th17 cells. Ciccia et al. showed human evidence for HLA-B27's role in gut inflammation. They have observed that HLA-B27 misfolding occurs in the gut of AS patients and is associated with activation of autophagy. Autophagy appears to induce intestinal expression of IL-23 in the human gut (89).

Furthermore, Utriainen et al. (90) reported a significantly decreased subset of intestinal dendritic cells (DCs), which are involved in maintaining self-tolerance, in the mesenteric lymph nodes (MLNs) and gut draining lymph of HLA-B27-tg (33-3) rats. The deficiency of these tolerogenic DCs in combination with the improved ability of bone marrow-derived DCs to stimulate IL-17 production by CD4+ T cells could induce an immune mediated inflammatory response involving the IL-23/ IL-17 axis. Possibly, the dysbalance in proinflammatory and 
toloregenic DCs as well as the HLA-B27 misfolding as observed in these experimental animal models $(86,91,92)$, might also be relevant for induction of disease in HLA-B27+ individuals.

In HLA-B27 tg (33-3) rats it was observed that HLA-B27 homodimer expression on various lymphocyte populations increases between week 6-23 of age, and is accompanied by colitis development and expansion of IL17+ CD4+ T cells and $\mathrm{TNF}+\mathrm{CD} 4+\mathrm{T}$ cells. Of interest, presence of HLA-B27 homodimer expression on monocytes in gut draining MLN, but not on splenocytes, co-occurred with the expansion of Th17 cells, when colitis was first observed. Besides HLA-B27 misfolding, HLA-B27 homodimerization is proposed as another mechanism by which HLA-B27 can contribute to IL-17 production, which has been reviewed previously (93-95). HLA-B27 is normally present on the cellular surface with $\beta_{2} \mathrm{~m}$ as a heterodimer, however when presented as a homodimer, this homodimer can interact with killer-cell immunoglobulin-like receptors (KIRs) on the surface of NK cells and T cells. This could result in direct activation of NK cells and $\mathrm{T}$ cells and aberrant cytokine production, contributing to an enhanced activation of the IL-23/IL-17 pathway (96).

The evidence for the role of the IL-23/IL-17 axis in colitis preceding joint inflammation was further provided by Glatigny (91). In the HLA-B27 tg (33-3 line) rats Glatigny et al. observed increased IL-17+TNF+ T cells in MLN which coincided with colitis, and later this was followed by the occurrence of the same cell types in PLN at the same time as the onset of arthritis. The increase in IL-17A+TNF+ T cells was paralleled by elevated mRNA expression levels of several genes indicating a Th17 phenotype (i.e. Il-21, Il-22, and Rorc) and increased serum levels of IL-17A (91).

These studies add to the concept that immune dysregulation in the gut precedes the onset of other clinical manifestations of SpA, possibly mediated by dysbiosis and/or colitis. They suggest that IL-23 produced in the gut could influence local activation of lymphoid cells in the entheses $(47,64)$. Various innate immune lymphoid cells able to produce these cytokines have been implicated in human SpA pathogenesis (reviewed in Gracey et al.) (71). If the IL-17+ T cells present in the gut mucosa are indeed pathogenic and if they play a role in the migration of immune cells from the gut to the joints needs further investigation. That lymphocytes can possibly egress from gut to joint prior to disease onset was suggested in a study in $\mathrm{TNF}^{\triangle \mathrm{ARE}}$ mice, reported as a conference abstract, where lymphocytes were shown to traffic from the colon to the joints (97). Ciccia et al. provided data, supporting active gut-joint trafficking in human axSpA. They showed an expanded gut-derived IL-17+ and IL-22+ ILC3 population expressing $\alpha 4 \beta 7$ in the peripheral blood, synovial fluid and inflamed bone marrow of patients (98).

Dysbiosis is an alteration in the composition of complex commensal or microbiota that might be induced by a wide range of environmental factors (99). Related to colitis, dysbiosis is suggested as an important factor that drives pathologic immune pathways. In HLA-B27 tg rats (33-3) it was shown that gut metabolomic changes are already present before the onset of colitis suggesting that these alterations might be an initiating event, however if these changes affect the IL-23/IL-17 pathway was not investigated (100). Gill et al. investigated microbial dysbiosis in different HLA-B27 rat strains and found no common overlapping microbial pattern but showed that the genetic background determined the dysbiotic microbial pattern present in each model. Nevertheless, microbial dysbiosis (regardless of the pattern) provoked similar immune response with an obvious increase in IL-23 and IL-17, as well as IL-1, IFN- $\gamma$, and TNF- $\alpha$ cytokines coinciding with colitis as early as 2 months of age in the various strains (101).

Gut microbes triggering the immune system were also observed in the SKG mouse models of SpA. Observations in the ZAP-70 ${ }^{\mathrm{W} 163 \mathrm{C}}$ mutant SKG mice and TLR-4-deficient SKG mice have confirmed the role of gut microbiota and therelated colitis in SpA. In contrast to the germ free SKG mice, that are free of all microorganisms including those that are typically found in the gut, the curdlan treated specific pathogen fee (SPF) SKG mice show increased constitutive $\mathrm{Il}-23$ expression specifically in ileal tissue, associated with ER stress marker expression and MLNs cytokine production including Il-6, Tnf- $\alpha$, Ifn- $\gamma$ and Il-17A (64). Involvement of gut microbes was reported by Rehaume et al. who showed that (intraperitoneal) curdlan administration induced acute systemic inflammation with IL-6, TNF, MCP-1 production and neutrophil recruitment disregarding the presence of the SKG allele or microbiota, with the response diminishing earlier in the germ-free animals. Neutrophil IL-17A production in the peritoneal cavity was shown to be microbiota dependent, as was ER-stress induced increased ileal IL-23 expression, MLN IL-17A expression, goblet cell loss, and ileitis development. In contrast, the development of associated arthritis and spondylitis was not crucially dependent on the microbiota profile, but incidence of arthritis and its severity clearly differed with various microbial profiles (102). These studies provide a link of microbial innate immune triggering in gut to development of SpA features. These microbiome alterations may be further induced by the tissue inflammation in the gut, making it difficult to determine what the initiating factor was: the dysbiosis or the tissue inflammation? (103). In human SpA, dysbiosis has been seen both in patients (104) as well as in healthy HLA-B27+ individuals (105), and it remains speculative if dysbiosis lowers the threshold for gut inflammation, and the onset of SpA.

\section{SKIN}

Psoriasis is an extra-musculoskeletal manifestation often seen in SpA patients (4), in particular in a subtype of SpA, psoriatic arthritis (PsA). The proinflammatory role of IL-17A in the development of articular and cutaneous manifestations of PsA has been consistently established in animal models as well as in human PsA. Here, we highlight the animal models that describe the concomitant presence of psoriasis and musculoskeletal manifestations.

In wild type C57BL/6J mice, as early as 1 day after IL-17A mc gene transfer, clinical psoriatic changes were observed, accompanied by an inflammatory infiltrate of neutrophils. Moreover, gene expression of murine keratin 16 (K16), a marker of keratinocyte hyper-proliferation was highly expressed. It remains to be assessed which cells are responsible for both the skin inflammation as well as the joint and bone pathology (106). 
Recently, additional novel animal models demonstrating the cutaneous, articular, and associated bone changes of psoriatic arthritis were developed. Yang et al. showed in the R26STAT3C ${ }^{\text {stopfl/fl }}$ CD4Cre mice SpA like disease, which is driven by an amplified Th17 response downstream of T cellspecific expression of a hyperactive STAT3C allele $(55,56)$. Animals developed psoriasis-like skin lesions after 5 weeks with increased infiltration of single IL-17+, IL-22+ or combined IL-17/IL-22+ CD4+ T cells. The associated Achilles tendon enthesitis showed increased cell infiltration with both IL23R and ROR $\gamma t$ double positive CD4+ T cells. These findings imply that Th17 cells play an important role in the development of skin and entheseal inflammation (56).

The importance of STAT3 in psoriatic skin inflammation was also shown when specifically activated in keratinocytes in the K5.STAT3C:F759 mice model. Yamamoto et al. demonstrated that early occurrence of arthritis in K5.STAT3C:F759 mice was due to coincident skin inflammation induced by a hyper STAT3 activation. Mice showed increased serum IL-6 and IL-17A levels. IL-17A expression was elevated compared with F759 mice in inflamed joints, which contain increased numbers of CCR6+ CD4+ T cells compared to the LN compartment (36).

Although these 3 models clearly show involvement of the IL23/IL-17 axis in development of psoriasis and arthritis, development of arthritis was not preceded by psoriasis but occurred simultaneously.

Skin inflammation preceding joint inflammation was addressed in F759 (not harboring the K5.STAT3C transgene) mice. These mice are known to spontaneously develop arthritis after 12-18 month. It was also shown that forced induction of psoriasis-like lesions by imiquimod application in these mice significantly accelerated arthritis development, suggesting that psoriatic inflammation facilitated arthritis development, possibly by activating the IL-17 pathway, as IL-17+ $\gamma \delta$ T cells as well as Th17 cells were present in the inflamed skin. However, other options should not be ruled out as imiquimod can also have important systemic effects (36). Recently a study reported (currently only available in abstract) that psoriasis-like skin inflammation in C57/B16 male mice induced mild synovial joint inflammation. Similar results were obtained after dextran sodium sulphate (DSS) colitis induction in these mice (107).

These preliminary data indicate that the skin is a candidate location for triggering joint pathology. Besides follow-up studies in animal models resembling PsA, future longitudinal studies in patients with psoriasis at increased risk of development of PsA, are expected to provide further insight into the mechanisms triggering joint disease in PsA. Future studies could benefit from applying state of the art molecular imaging in combination with (serial) tissue biopsy analysis to repetitively assess tissue inflammation.

\section{CONCLUSION AND FUTURE PERSPECTIVES}

Literature on the animal models resembling human SpA indicates an overlapping and distinctive role of IL-17A and IL23 in the initiation of disease. There is initial evidence for inflammation at gut and skin to precede joint inflammation in animal models of SpA with involvement of the IL-23/IL-17 axis. Importantly, in accordance with the insights from the M.tb HLAB27 study $(24,27)$, IL-23 plays an important role in the onset of SpA-like pathology in many animal models, even before clinical joint manifestations are present, which is in clear contrast with the absence of any significant clinical effect as observed when blocking IL23R in diseased rats (24) or with blocking of IL-23p19 in AS patients (25). The data in animal models may help us to understand which pathways are dysregulated early in the disease process, in the pre-clinical phase, and if these dysregulations differ from observations in established disease.

While animal models provide an ideal basis for in-depth molecular analysis of target tissues in SpA to elucidate causal relationships between the upregulation of specific immune pathways and development of key SpA features, complimentary studies performing serial advanced molecular imaging or biosample collection in individuals with an increased risk of developing SpA or PsA, or in patients who have been recently diagnosed withSpA, are essentially required if we want to translate findings in animal models of SpA to human disease. The goal of studying the preclinical stage of the disease would be to find better diagnostic markers to allow an earlier diagnosis and open up opportunities for preventive treatment strategies (108-110). If IL23 dysregulation in the pre-clinical phase of disease, as observed in various animal models, can be confirmed in human pre-clinical SpA, it could be speculated that IL-23 targeting may be effective in preventing disease, in contrast to the lack of effect observed with IL-23 blocking in established SpA. There is more recent evidence that Th17 cells in the synovial tissue are polyfunctional and produce multiple proinflammatory cytokines that synergize with IL-17A. Treatments targeting Th17 cells, or affecting multiple cytokines that synergize with IL-17A in pathogenic immune responses could also be considered for preventive trials, Whether these pathways are upregulated early in the disease pathogenesis remains to be elucidated. As an example, potential novel treatments such as TYK2 inhibition (108), mTOR inhibition by rapamycin (110), and PI3K $\delta$ inhibition (109) have been shown in vitro and/or in vivo animal models to affect multiple cytokines relevant for SpA pathogenesis. Lastly, it remains to be studied if preclinical treatment in patients could prevent or affect pathologic bone formation, as this remains an unmet treatment need in SpA patients.

The IL-23/IL-17 axis is clearly implicated in disease initiation in SpA. However, which specific innate (-like) or adaptive immune cells are responsible for the pathogenic IL-17A production in the various target tissues, is still incompletely understood. Moreover, the effects of the plasticity of the Th17/Treg cells in initiating inflammation as well as the pathogenic role of pathways that enable IL-23 independent IL-17A production are still incompletely understood and prompt further research both in human SpA as in animal models resembling SpA.

To conclude, animal models have improved our understanding of the IL-23/IL-17 axis in SpA and continue to allow us to gain novel insights on SpA pathogenesis. Greater understanding of disease initiation in $\mathrm{SpA}$ animal models could 
support human preclinical SpA studies, This may provide a basis for better future preventive approaches for our patients.

\section{AUTHOR CONTRIBUTIONS}

MM, SC, and MS: substantial contributions to conception and design, MM, SC and MS: drafted the article, over viewed it critically for important intellectual content and given final approval of the final version. All authors contributed to the article and approved the submitted version.

\section{REFERENCES}

1. Braun J, Sieper J. Ankylosing Spondylitis. Lancet (2007) 369:1379-90. doi: 10.1016/S0140-6736(07)60635-7

2. Van Der LS, Valkenburg HA. Cats A. Evaluation of Diagnostic Criteria for Ankylosing Spondylitis. Arthritis Rheum (1984) 27(4):361-8. doi: 10.1002/ art.1780270401

3. Deodhar A. Axial Spondyloarthritis Criteria and Modified NY Criteria: Issues and Controversies. Clin Rheumatol (2014) 33(6):741-7. doi: 10.1007/ s10067-014-2661-8

4. Dougados M, Baeten D. Spondyloarthritis. Lancet Publ Group (2011) 377:2127-37. doi: 10.1016/S0140-6736(11)60071-8

5. Baeten D, Sieper J, Braun J, Baraliakos X, Dougados M, Emery P, et al. Secukinumab, An Interleukin-17A Inhibitor, in Ankylosing Spondylitis. N Engl J Med (2015) 373(26):2534-48. doi: 10.1056/NEJMoa1505066

6. Baraliakos X, Braun J, Deodhar A, Poddubnyy D, Kivitz A, Tahir H, et al. Long-Term Efficacy and Safety of Secukinumab $150 \mathrm{Mg}$ in Ankylosing Spondylitis: 5-Year Results From the Phase III MEASURE 1 Extension Study. RMD Open (2019) 5(2):1005. doi: 10.1136/rmdopen-2019-001005

7. Locksley RM, Killeen N, Lenardo MJ. The TNF and TNF Receptor Superfamilies: Integrating Mammalian Biology. Cell (2001) 104:487-501. doi: 10.1016/S0092-8674(01)00237-9

8. Campbell IK, Roberts LJ, Wicks IP. Molecular Targets in Immune-Mediated Diseases: The Case of Tumour Necrosis Factor and Rheumatoid Arthritis. Immunol Cell Biol (2003) 81(5):354-66. doi: 10.1046/j.0818-9641.2003.01185.x

9. Faustman D, Davis M. TNF Receptor 2 Pathway: Drug Target for Autoimmune Diseases. Nat Rev Drug Discov (2010) 9:482-93. doi: $10.1038 / \mathrm{nrd} 3030$

10. Ruddy MJ, Wong GC, Liu XK, Yamamoto H, Kasayama S, Kirkwood KL, et al. Functional Cooperation Between Interleukin-17 and Tumor Necrosis Factor- $\alpha$ Is Mediated by CCAAT/Enhancer-Binding Protein Family Members. J Biol Chem (2004) 279(4):2559-67. doi: 10.1074/jbc.M308809200

11. Hymowitz SG, Filvaroff EH, Yin JP, Lee J, Cai L, Risser P, et al. Il-17s Adopt a Cystine Knot Fold: Structure and Activity of a Novel Cytokine, IL-17F, and Implications for Receptor Binding. EMBO J (2001) 20(19):5332-41. doi: 10.1093/emboj/20.19.5332

12. Yang J, Yang M, Htut TM, Ouyang X, Hanidu A, Li X, et al. Epstein-Barr Virus-Induced Gene 3 Negatively Regulates IL-17, Il-22 and Roryt. Eur J Immunol (2008) 38(5):1204-14. doi: 10.1002/eji.200838145

13. Amatya N, Garg AV, Gaffen SL. Il-17 Signaling: The Yin and the Yang. Trends Immunol Elsevier Ltd (2017) 38:310-22. doi: 10.1016/j.it.2017.01.006

14. Oppmann B, Lesley R, Blom B, Timans JC, Xu Y, Hunte B, et al. Novel p19 Protein Engages IL-12p40 to Form a Cytokine, IL-23, With Biological Activities Similar as Well as Distinct From IL-12. Immunity (2000) 13 (5):715-25. doi: 10.1016/S1074-7613(00)00070-4

15. Teng MWL, Bowman EP, McElwee JJ, Smyth MJ, Casanova JL, Cooper AM, et al. Il-12 and IL-23 Cytokines: From Discovery to Targeted Therapies for Immune-Mediated Inflammatory Diseases. Nat Med Nat Publ Group (2015) 21:719-29. doi: 10.1038/nm.3895

16. Hassane M, Jouan Y, Creusat F, Soulard D, Boisseau C, Gonzalez L, et al. Interleukin-7 Protects Against Bacterial Respiratory Infection by Promoting IL-17A-Producing Innate T-Cell Response. Mucosal Immunol (2020) 13 (1):128-39. doi: 10.1038/s41385-019-0212-y

\section{FUNDING}

MM is supported by a Dutch Arthritis Society grant (number 191-206).

\section{ACKNOWLEDGMENTS}

We thank Leonie M. van Duivenvoorde for critically reading the manuscript.

17. Webster KE, Kim HO, Kyparissoudis K, Corpuz TM, Pinget GV, Uldrich AP, et al. IL-17-Producing NKT Cells Depend Exclusively on IL-7 for Homeostasis and Survival. Mucosal Immunol (2014) 7(5):1058-67. doi: 10.1038/mi.2013.122

18. Gracey E, Qaiyum Z, Almaghlouth I, Lawson D, Karki S, Avvaru N, et al. IL7 Primes IL-17 in Mucosal-Associated Invariant T (MAIT) Cells, Which Contribute to the Th17-Axis in Ankylosing Spondylitis. Ann Rheum Dis (2016) 75(12):2124-32. doi: 10.1136/annrheumdis-2015-208902

19. Busman-Sahay KO, Walrath T, Huber S, O'Connor W. Cytokine Crowdsourcing: Multicellular Production of T H 17-Associated Cytokines. J Leukoc Biol (2015) 97(3):499-510. doi: 10.1189/jlb.3RU0814-386R

20. Cuthbert RJ, Watad A, Fragkakis EM, Dunsmuir R, Loughenbury P, Khan A, et al. Evidence That Tissue Resident Human Enthesis $\gamma \delta$ t-Cells can Produce IL-17A Independently of IL-23R Transcript Expression. Ann Rheum Dis (2019) 78(11):1559-65. doi: 10.1136/annrheumdis-2019-215210

21. Chyuan IT, Chen JY. Role of Interleukin- (IL-) 17 in the Pathogenesis and Targeted Therapies in Spondyloarthropathies. Mediators Inflamm (2018) 2018:2403935. doi: 10.1155/2018/2403935

22. Ritchlin C, Rahman P, Kavanaugh A, McInnes IB, Puig L, Li S, et al. Efficacy and Safety of the Anti-IL-12/23 p40 Monoclonal Antibody, Ustekinumab, in Patients With Active Psoriatic Arthritis Despite Conventional nonBiological and Biological Anti-Tumour Necrosis Factor Therapy: 6-Month and 1-Year Results of the Phase 3, Multicentre, Double-Blind, Placebocontrolled, Randomised PSUMMIT 2 Trial. Ann Rheum Dis (2014) 73(6):990-9. doi: 10.1136/annrheumdis-2013-204655

23. Deodhar A, Gottlieb AB, Boehncke WH, Dong B, Wang Y, Zhuang Y, et al. Efficacy and Safety of Guselkumab in Patients With Active Psoriatic Arthritis: A Randomised, Double-Blind, Placebo-Controlled, Phase 2 Study. Lancet (2018) 391(10136):2213-24. doi: 10.1136/annrheumdis2018-eular.2059

24. van Tok MN, Na S, Lao CR, Alvi M, Pots D, van de Sande MGH, et al. The Initiation, But Not the Persistence, of Experimental Spondyloarthritis Is Dependent on Interleukin-23 Signaling. Front Immunol (2018) 9:1550. doi: 10.3389/fimmu.2018.01550

25. Baeten D, Østergaard M, Wei JCC, Sieper J, Järvinen P, Tam LS, et al. Risankizumab, an IL-23 Inhibitor, for Ankylosing Spondylitis: Results of a Randomised, Double-Blind, Placebo-Controlled, Proof-of-Concept, DoseFinding Phase 2 Study. Ann Rheum Dis (2018) 77(9):1295-302. doi: 10.1136/ annrheumdis-2018-213328

26. Baeten D, Baraliakos X, Braun J, Sieper J, Emery P, van der Heijde D, et al. AntiInterleukin-17A Monoclonal Antibody Secukinumab in Treatment of Ankylosing Spondylitis: A Randomised, Double-Blind, Placebo-Controlled Trial. Lancet (2013) 382(9906):1705-13. doi: 10.1016/S0140-6736(13)61134-4

27. van Tok MN, Satumtira N, Dorris M, Pots D, Slobodin G, van de Sande MG, et al. Innate Immune Activation Can Trigger Experimental Spondyloarthritis in HLA-B27/Huß2m Transgenic Rats. Front Immunol (2017) 8:920. doi: 10.3389/fimmu.2017.00920

28. Deodhar A, Gensler LS, Sieper J, Clark M, Calderon C, Wang Y, et al. Three Multicenter, Randomized, Double-Blind, Placebo-Controlled Studies Evaluating the Efficacy and Safety of Ustekinumab in Axial Spondyloarthritis. Arthritis Rheumatol (2019) 71(2):258-70. doi: 10.1002/art.40728

29. Gerlag DM, Raza K, Van Baarsen LGM, Brouwer E, Buckley CD, Burmester GR, et al. EULAR Recommendations for Terminology and Research in 
Individuals at Risk of Rheumatoid Arthritis: Report From the Study Group for Risk Factors for Rheumatoid Arthritis. Ann Rheum Dis (2012) 71:63841. doi: 10.1136/annrheumdis-2011-200990

30. Malmström V, Catrina AI, Klareskog L. The Immunopathogenesis of Seropositive Rheumatoid Arthritis: From Triggering to Targeting. Nat Rev Immunol (2017) 17:60-75. doi: 10.1038/nri.2016.124

31. Petrovská N, Prajzlerová K, Vencovský J, Šenolt L, Filková M. The PreClinical Phase of Rheumatoid Arthritis: From Risk Factors to Prevention of Arthritis. Autoimmun Rev (2021) 20(5):102797. doi: 10.1016/j.autrev.2021. 102797

32. Gerlag DM, Safy M, Maijer KI, Tang MW, Tas SW, Starmans-Kool MJF, et al. Effects of B-Cell Directed Therapy on the Preclinical Stage of Rheumatoid Arthritis: The PRAIRI Study. Ann Rheum Dis (2019) 78 (2):179-85. doi: 10.1136/annrheumdis-2017-212763

33. Bos WH, Dijkmans BAC, Boers M, Van De Stadt RJ, Van Schaardenburg D. Effect of Dexamethasone on Autoantibody Levels and Arthritis Development in Patients With Arthralgia: A Randomised Trial. Ann Rheum Dis (2010) 69(3):571-4. doi: 10.1136/ard.2008.105767

34. Taams LS, Steel KJA, Srenathan U, Burns LA, Kirkham BW. Il-17 in the Immunopathogenesis of Spondyloarthritis. Nat Rev Rheumatol (2018) 14:453-66. doi: 10.1038/s41584-018-0044-2

35. Vieira-Sousa E, Van Duivenvoorde LM, Fonseca JE, Lories RJ, Baeten DL. Review: Animal Models as a Tool to Dissect Pivotal Pathways Driving Spondyloarthritis. Arthritis Rheumatol John Wiley Sons Inc (2015) 67:281327. doi: 10.1002 /art.39282

36. Yamamoto M, Nakajima K, Takaishi M, Kitaba S, Magata Y, Kataoka S, et al. Psoriatic Inflammation Facilitates the Onset of Arthritis in a Mouse Model. J Invest Dermatol (2015) 135(2):445-53. doi: 10.1038/jid.2014.426

37. Dibra D, Xia X, Gagea M, Lozano G, Li S. A Spontaneous Model of Spondyloarthropathies That Develops Bone Loss and Pathological Bone Formation: A Process Regulated by IL27RA-/- and Mutant-P53. PloS One (2018) 13(3):e0193485. doi: 10.1371/journal.pone.0193485

38. Hammer RE, Maika SD, Richardson JA, Tang JP, Taurog JD. Spontaneous Inflammatory Disease in Transgenic Rats Expressing HLA-B27 and Human B2m: An Animal Model of HLA-B27-Associated Human Disorders. Cell (1990) 63(5):1099-112. doi: 10.1016/0092-8674(90)90512-D

39. Ramos M, Alvarez I, Sesma L, Logean A, Rognan D, De López Castro JA. Molecular Mimicry of an HLA-B27-Derived Ligand of Arthritis-Linked Subtypes With Chlamydial Proteins. J Biol Chem (2002) 277(40):37573-81. doi: 10.1074/jbc.M205470200

40. Khare SD, Hansen J, Luthra HS, David CS. Hla-B27 Heavy Chains Contribute to Spontaneous Inflammatory Disease in B27/Human 2-Microglobulin (2 M) Double Transgenic Mice With Disrupted Mouse 2 M Key Words: HLA-B27 • Spondyloarthropathy $\bullet$ Reiter's Disease $\bullet$ Animal Model $\bullet$ Heavy Chain. J Clin Invest (1996) 98(12):2746-55. doi: 10.1172/JCI119100

41. Tran TM, Dorris ML, Satumtira N, Richardson JA, Hammer RE, Shang J, et al. Additional Human 32 -Microglobulin Curbs HLA-B27 Misfolding and Promotes Arthritis and Spondylitis Without Colitis in Male HLA-B27-transgenic Rats. Arthritis Rheumatol (2006) 54(4):1317-27. doi: 10.1002/art.21740

42. Armaka M, Apostolaki M, Jacques P, Kontoyiannis DL, Elewaut D, Kollias G. Mesenchymal Cell Targeting by TNF as a Common Pathogenic Principle in Chronic Inflammatory Joint and Intestinal Diseases. J Exp Med (2008) 205 (2):331-7. doi: 10.1084/jem.20070906

43. Jacques P, Lambrecht S, Verheugen E, Pauwels E, Kollias G, Armaka M, et al. Proof of Concept: Enthesitis and New Bone Formation in Spondyloarthritis Are Driven by Mechanical Strain and Stromal Cells. Ann Rheum Dis (2014) 73(2):437-45. doi: 10.1136/annrheumdis-2013-203643

44. Kontoyiannis D, Pasparakis M, Pizarro TT, Cominelli F, Kollias G. Impaired on/Off Regulation of TNF Biosynthesis in Mice Lacking TNF AU- Rich Elements: Implications for Joint and Gut-Associated Immunopathologies. Immunity (1999) 10(3):387-98. doi: 10.1016/S1074-7613(00)80038-2

45. Kaaij MH, van Tok MN, Blijdorp IC, Ambarus CA, Stock M, Pots D, et al. Transmembrane TNF Drives Osteoproliferative Joint Inflammation Reminiscent of Human Spondyloarthritis. J Exp Med (2020) 217(10): e20200288. doi: 10.1084/jem.20200288

46. Redlich K, Görtz B, Hayer S, Zwerina J, Kollias G, Steiner G, et al. Overexpression of Tumor Necrosis Factor Causes Bilateral Sacroiliitis. Arthritis Rheum (2004) 50(3):1001-5. doi: 10.1002/art.20194
47. Sherlock JP, Joyce-Shaikh B, Turner SP, Chao CC, Sathe M, Grein J, et al. Il23 Induces Spondyloarthropathy by Acting on ROR- $\gamma \mathrm{t}+\mathrm{CD} 3+\mathrm{Cd} 4-\mathrm{CD} 8-$ Entheseal Resident T Cells. Nat Med (2012) 18(7):1069-76. doi: 10.1038/ nm. 2817

48. Sakaguchi S. Naturally Arising CD4+ Regulatory T Cells for Immunologic SelfTolerance and Negative Control of Immune Responses. Annu Rev Immunol (2004) 22:531-62. doi: 10.1146/annurev.immunol.21.120601.141122

49. Yoshitomi H, Sakaguchi N, Kobayashi K, Brown GD, Tagami T, Sakihama T, et al. A Role for Fungal $\beta$-Glucans and Their Receptor Dectin-1 in the Induction of Autoimmune Arthritis in Genetically Susceptible Mice. J Exp Med (2005) 201(6):949-60. doi: 10.1084/jem.20041758

50. Ruutu M, Thomas G, Steck R, Degli-Esposti MA, Zinkernagel MS, Alexander $\mathrm{K}$, et al. $\beta$-Glucan Triggers Spondylarthritis and Crohn's Disease-Like Ileitis in SKG Mice. Arthritis Rheumatol (2012) 64(7):221122. doi: 10.1002/art.34423

51. Diveu C, McGeachy MJ, Boniface K, Stumhofer JS, Sathe M, Joyce-Shaikh B, et al. Il-27 Blocks Rorc Expression to Inhibit Lineage Commitment of Th17 Cells. J Immunol (2009) 182(9):5748-56. doi: 10.4049/jimmunol.0801162

52. Wang X, Kua HY, Hu Y, Guo K, Zeng Q, Wu Q, et al. p53 Functions as a Negative Regulator of Osteoblastogenesis, Osteoblast-Dependent Osteoclastogenesis, and Bone Remodeling. J Cell Biol (2006) 172(1):11525. doi: $10.1083 / \mathrm{jcb} .200507106$

53. Zhang S, Zheng M, Kibe R, Huang Y, Marrero L, Warren S, et al. Trp53 Negatively Regulates Autoimmunity Via the STAT3-Th17 Axis. FASEB J (2011) 25(7):2387-98. doi: 10.1096/fj.10-175299

54. Dong C. TH17 Cells in Development: An Updated View of Their Molecular Identity and Genetic Programming. Nat Rev Immunol (2008) 8:337-48. doi: $10.1038 /$ nri2295

55. Casola S, Cattoretti G, Uyttersprot N, Koralov SB, Segal J, Hao Z, et al. Tracking Germinal Center B Cells Expressing Germ-Line Immunoglobulin $\gamma 1$ Transcripts by Conditional Gene Targeting. Proc Natl Acad Sci USA (2006) 103(19):7396-401. doi: 10.1073/pnas.0602353103

56. Yang L, Fanok MH, Mediero-Munoz A, Fogli LK, Corciulo C, Abdollahi S, et al. Augmented Th17 Differentiation Leads to Cutaneous and SynovioEntheseal Inflammation in a Novel Model of Psoriatic Arthritis. Arthritis Rheumatol (2018) 70(6):855-67. doi: 10.1002/art.40447

57. Cénit MC, Ortego-Centeno N, Raya E, Callejas JL, García-Hernandez FJ, Castillo-Palma MJ, et al. Influence of the STAT3 Genetic Variants in the Susceptibility to Psoriatic Arthritis and Behcet's Disease. Hum Immunol (2013) 74(2):230-3. doi: 10.1016/j.humimm.2012.10.019

58. Lories RJU, Matthys P, De Vlam K, Derese I, Luyten FP. Ankylosing Enthesitis, Dactylitis, and Onychoperiostitis in Male DBA/1 Mice: A Model of Psoriatic Arthritis. Ann Rheum Dis (2004) 63(5):595-8. doi: 10.1136/ard.2003.013599

59. Corthay A, Hansson AS, Holmdahl R. T Lymphocytes are Not Required for the Spontaneous Development of Entheseal Ossification Leading to Marginal Ankylosis in the DBA/1 Mouse. Arthritis Rheum (2000) 43(4):844-51. doi: 10.1002/1529-0131(200004)43:4<844::AID-ANR15>3.0.CO;2-B

60. Taylor GA, Carballo E, Lee DM, Lai WS, Thompson MJ, Patel DD, et al. A Pathogenetic Role for Tnfo in the Syndrome of Cachexia, Arthritis, and Autoimmunity Resulting From Tristetraprolin (TTP) Deficiency. Immunity (1996) 4(5):445-54. doi: 10.1016/S1074-7613(00)80411-2

61. Molle C, Zhang T, De Lendonck LY, Gueydan C, Andrianne M, Sherer F, et al. Tristetraprolin Regulation of Interleukin 23 mRNA Stability Prevents a Spontaneous Inflammatory Disease. J Exp Med (2013) 210(9):1675-84. doi: $10.1084 /$ jem. 20120707

62. Reinhardt A, Yevsa T, Worbs T, Lienenklaus S, Sandrock I, Oberdörfer L, et al. Interleukin-23-Dependent $\gamma / \delta$ T Cells Produce Interleukin-17 and Accumulate in the Enthesis, Aortic Valve, and Ciliary Body in Mice. Arthritis Rheumatol (2016) 68(10):2476-86. doi: 10.1002/art.39732

63. Brown GD, Gordon S. Fungal $\beta$-Glucans and Mammalian Immunity. Immun Cell Press (2003) 19:311-5. doi: 10.1016/S1074-7613(03)00233-4

64. Benham H, Rehaume LM, Hasnain SZ, Velasco J, Baillet AC, Ruutu M, et al. Interleukin-23 Mediates the Intestinal Response to Microbial $\beta$-1,3-Glucan and the Development of Spondyloarthritis Pathology in SKG Mice. Arthritis Rheumatol (2014) 66(7):1755-67. doi: 10.1002/art.38638

65. van Tok MN, van Duivenvoorde LM, Kramer I, Ingold P, Pfister S, Roth L, et al. Interleukin-17A Inhibition Diminishes Inflammation and New Bone 
Formation in Experimental Spondyloarthritis. Arthritis Rheumatol (2019) 71 (4):612-25. doi: 10.1002/art.40770

66. Mitra A, Raychaudhuri SPSK, Raychaudhuri SPSK. Functional Role of IL-22 in Psoriatic Arthritis. Arthritis Res Ther (2012) 14(2):R65. doi: 10.1186/ ar3781

67. Cuthbert RJ, Fragkakis EM, Dunsmuir R, Li Z, Coles M, Marzo-Ortega H, et al. Brief Report: Group 3 Innate Lymphoid Cells in Human Enthesis. Arthritis Rheumatol (2017) 69(9):1816-22. doi: 10.1002/art.40150

68. Bridgewood C, Watad A, Russell T, Palmer TM, Marzo-Ortega H, Khan A, et al. Identification of Myeloid Cells in the Human Enthesis as the Main Source of Local IL-23 Production. Ann Rheum Dis (2019) 78(7):929-33. doi: 10.1136/annrheumdis-2018-214944

69. Watad A, Rowe H, Newton D, Bridgewood C, McGonagle DG, Watad A, et al. Is a Human In Vitro Enthesitis Model Relevant to SpA-associated Enthesitis? Response to: $€$ Beware of Wolves in Sheep's Clothing: Immune Cell Plasticity and Instability in Health and Disease' by Alunno Et Al. Ann Rheum Dis (2020) annrheumdis-2020-218151. doi: 10.1136/annrheumdis2020-218151

70. Van Praet L, Jans L, Carron P, Jacques P, Glorieus E, Colman R, et al. Degree of Bone Marrow Oedema in Sacroiliac Joints of Patients With Axial Spondyloarthritis Is Linked to Gut Inflammation and Male Sex: Results From the GIANT Cohort. Ann Rheum Dis (2014) 73(6):1186-9. doi: 10.1136/annrheumdis-2013-203854

71. Gracey E, Vereecke L, McGovern D, Fröhling M, Schett G, Danese S, et al. Revisiting the Gut-Joint Axis: Links Between Gut Inflammation and Spondyloarthritis. Nat Rev Rheumatol Nat Res (2020) 16:415-33. doi: 10.1038/s41584-020-0454-9

72. Michielan A, D’Incà R. Intestinal Permeability in Inflammatory Bowel Disease: Pathogenesis, Clinical Evaluation, and Therapy of Leaky Gut. Mediators Inflamm (2015) 2015:628157. doi: 10.1155/2015/628157

73. Bischoff SC, Barbara G, Buurman W, Ockhuizen T, Schulzke JD, Serino M, et al. Intestinal Permeability - A New Target for Disease Prevention and Therapy. BMC Gastroenterol (2014) 14:189. doi: 10.1186/s12876-014-0189-7

74. Rath HC, Herfarth HH, Ikeda JS, Grenther WB, Hamm TE, Balish E, et al. Normal Luminal Bacteria, Especially Bacteroides Species, Mediate Chronic Colitis, Gastritis, and Arthritis in HLA-B27/human $\beta 2$ Microglobulin Transgenic Rats. J Clin Invest (1996) 98(4):945-53. doi: 10.1172/JCI1 18878

75. Lee JS, Tato CM, Joyce-Shaikh B, Gulan F, Cayatte C, Chen Y, et al. Interleukin-23-Independent IL-17 Production Regulates Intestinal Epithelial Permeability. Immunity (2015) 43(4):727-38. doi: 10.1016/ j.immuni.2015.09.003

76. Withers DR, Hepworth MR, Wang X, Mackley EC, Halford EE, Dutton EE, et al. Transient Inhibition of ROR- $\gamma$ t Therapeutically Limits Intestinal Inflammation by Reducing TH17 Cells and Preserving Group 3 Innate Lymphoid Cells. Nat Med (2016) 22(3):319-23. doi: 10.1038/nm.4046

77. Leppkes M, Becker C, Ivanov II, Hirth S, Wirtz S, Neufert C, et al. RoryExpressing Th17 Cells Induce Murine Chronic Intestinal Inflammation Via Redundant Effects of IL-17A and IL-17F. Gastroenterology (2009) 136 (1):257-67. doi: 10.1053/j.gastro.2008.10.018

78. Feagan BG, Sandborn WJ, D’Haens G, Panés J, Kaser A, Ferrante M, et al. Induction Therapy With the Selective Interleukin-23 Inhibitor Risankizumab in Patients With Moderate-to-Severe Crohn's Disease: A Randomised, Double-Blind, Placebo-Controlled Phase 2 Study. Lancet (2017) 389(10080):1699-709. doi: 10.1016/S0140-6736(17)30570-6

79. Sands BE, Sandborn WJ, Panaccione R, O’Brien CD, Zhang H, Johanns J, et al. Ustekinumab as Induction and Maintenance Therapy for Ulcerative Colitis. N Engl J Med (2019) 381(13):1201-14. doi: 10.1056/NEJMoa1900750

80. Tang C, Kakuta S, Shimizu K, Kadoki M, Kamiya T, Shimazu T, et al. Suppression of IL-17F, But Not of IL-17A, Provides Protection Against Colitis by Inducing T Reg Cells Through Modification of the Intestinal Microbiota. Nat Immunol (2018) 19(7):755-65. doi: 10.1038/s41590-018-0134-y

81. Schmidt EGW, Larsen HL, Kristensen NN, Poulsen SS, Pedersen AML, Claesson MH, et al. TH17 Cell Induction and Effects of IL-17A and IL-17F Blockade in Experimental Colitis. Inflamm Bowel Dis (2013) 19(8):1567-76. doi: 10.1097/MIB.0b013e318286falc

82. Sugimoto K, Ogawa A, Mizoguchi E, Shimomura Y, Andoh A, Bhan AK, et al. IL-22 Ameliorates Intestinal Inflammation in a Mouse Model of Ulcerative Colitis. J Clin Invest (2008) 118(2):534-44. doi: 10.1172/JCI33194
83. Hasegawa M, Yada S, Liu MZ, Kamada N, Muñoz-Planillo R, Do N, et al. Interleukin-22 Regulates the Complement System to Promote Resistance Against Pathobionts After Pathogen-Induced Intestinal Damage. Immunity (2014) 41(4):620-32. doi: 10.1016/j.immuni.2014.09.010

84. Muñoz M, Eidenschenk C, Ota N, Wong K, Lohmann U, Kühl AA, et al. Interleukin-22 Induces Interleukin-18 Expression From Epithelial Cells During Intestinal Infection. Immunity (2015) 42(2):321-31. doi: 10.1016/ j.immuni.2015.01.011

85. Sakamoto K, Kim YG, Hara H, Kamada N, Caballero-Flores G, Tolosano E, et al. Il-22 Controls Iron-Dependent Nutritional Immunity Against Systemic Bacterial Infections. Sci Immunol (2017) 2(8):eaai8371. doi: 10.1126/ sciimmunol.aai8371

86. DeLay ML, Turner MJ, Klenk EI, Smith JA, Sowders DP, Colbert RA. HlaB27 Misfolding and the Unfolded Protein Response Augment Interleukin-23 Production and Are Associated With Th17 Activation in Transgenic Rats. Arthritis Rheum (2009) 60(9):2633-43. doi: 10.1002/art.24763

87. Schröder M, Kaufman RJ. The MAMMALIAN Unfolded PROTEIN Response. Annu Rev Biochem (2005) 74(1):739-89. doi: 10.1146/ annurev.biochem.73.011303.074134

88. Todd DJ, Lee AH, Glimcher LH. The Endoplasmic Reticulum Stress Response in Immunity and Autoimmunity. Nat Rev Immunol Nat Publ Group (2008) 8:663-74. doi: 10.1038/nri2359

89. Ciccia F, Accardo-Palumbo A, Rizzo A, Guggino G, Raimondo S, Giardina A, et al. Evidence That Autophagy, But Not the Unfolded Protein Response, Regulates the Expression of IL-23 in the Gut of Patients With Ankylosing Spondylitis and Subclinical Gut Inflammation. Ann Rheum Dis (2014) 73 (8):1566-74. doi: 10.1136/annrheumdis-2012-202925

90. Utriainen L, Firmin D, Wright P, Cerovic V, Breban M, Mcinnes I, et al. Expression of HLA-B27 Causes Loss of Migratory Dendritic Cells in a Rat Model of Spondylarthritis. Arthritis Rheum (2012) 64(10):3199-209. doi: 10.1002/art.34561

91. Glatigny S, Fert I, Blaton MA, Lories RJ, Araujo LM, Chiocchia G, et al. Proinflammatory Th17 Cells Are Expanded and Induced by Dendritic Cells in Spondylarthritis-Prone HLA-B27-Transgenic Rats. Arthritis Rheum (2012) 64(1):110-20. doi: 10.1002/art.33321

92. Turner MJ, DeLay ML, Bai S, Klenk E, Colbert RA. HLA-B27 Up-Regulation Causes Accumulation of Misfolded Heavy Chains and Correlates With the Magnitude of the Unfolded Protein Response in Transgenic Rats: Implications for the Pathogenesis of Spondylarthritis-Like Disease. Arthritis Rheum (2007) 56(1):215-23. doi: 10.1002/art.22295

93. Chen B, Li D, Xu W. Association of Ankylosing Spondylitis With HLA-B27 and ERAP1: Pathogenic Role of Antigenic Peptide. Med Hypotheses (2013) 80(1):36-8. doi: 10.1016/j.mehy.2012.10.003

94. Allen RL, Raine T, Haude A, Trowsdale J, Wilson MJ. Cutting Edge: Leukocyte Receptor Complex-Encoded Immunomodulatory Receptors Show Differing Specificity for Alternative Hla-B27 Structures. J Immunol (2001) 167(10):5543-7. doi: 10.4049/jimmunol.167.10.5543

95. Smith JA, Colbert RA. Review: The Interleukin-23/Interleukin-17 Axis in Spondyloarthritis Pathogenesis: Th17 and Beyond. Arthritis Rheumatol (Hoboken NJ) (2014) 66(2):231-41. doi: 10.1002/art.38291

96. Colbert RA, Tran TM, Layh-Schmitt G. Hla-B27 Misfolding and Ankylosing Spondylitis. Mol Immunol Mol Immunol (2014) 57:44-51. doi: 10.1016/ j.molimm.2013.07.013

97. Norman E, Lefferts A, Kuhn KA. Gut-Joint T Cell Trafficking in a Model of Bacteria-Driven Murine IBD-Spa [abstract]. Arthritis Rheumatol. (2018) 70 (suppl 10).

98. Ciccia F, Guggino G, Rizzo A, Saieva L, Peralta S, Giardina A, et al. Type 3 Innate Lymphoid Cells Producing IL-17 and IL-22 Are Expanded in the Gut, in the Peripheral Blood, Synovial Fluid and Bone Marrow of Patients With Ankylosing Spondylitis. Ann Rheum Dis (2015) 74(9):1739-47. doi: 10.1136/ annrheumdis-2014-206323

99. Carding S, Verbeke K, Vipond DT, Corfe BM, Owen LJ. Dysbiosis of the Gut Microbiota in Disease. Microb Ecol Heal Dis (2015) 26:10. doi: 10.3402/ mehd.v26.26191

100. Asquith M, Davin S, Stauffer P, Michell C, Janowitz C, Lin P, et al. Intestinal Metabolites are Profoundly Altered in the Context of HLA-B27 Expression and Functionally Modulate Disease in a Rat Model of Spondyloarthritis. Arthritis Rheumatol (2017) 69(10):1984-95. doi: 10.1002/art.40183 
101. Gill T, Asquith M, Brooks SR, Rosenbaum JT, Colbert RA. Effects of HLAB27 on Gut Microbiota in Experimental Spondyloarthritis Implicate an Ecological Model of Dysbiosis. Arthritis Rheumatol (2018) 70(4):555-65. doi: 10.1002/art.40405

102. Rehaume LM, Mondot S, Aguirre De Cárcer D, Velasco J, Benham H, Hasnain SZ, et al. Zap-70 Genotype Disrupts the Relationship Between Microbiota and Host, Leading to Spondyloarthritis and Ileitis in SKG Mice. Arthritis Rheumatol (2014) 66(10):2780-92. doi: 10.1002/art.38773

103. Ni J, Wu GD, Albenberg L, Tomov VT. Gut Microbiota and IBD: Causation or Correlation? HHS Public Access. Nat Rev Gastroenterol Hepatol (2017) 14 (10):573-84. doi: 10.1038/nrgastro.2017.88

104. Costello ME, Ciccia F, Willner D, Warrington N, Robinson PC, Gardiner B, et al. Brief Report: Intestinal Dysbiosis in Ankylosing Spondylitis. Arthritis Rheumatol (2015) 67(3):686-91. doi: 10.1002/art.38967

105. Asquith M, Sternes PR, Costello ME, Karstens L, Diamond S, Martin TM, et al. Hla Alleles Associated With Risk of Ankylosing Spondylitis and Rheumatoid Arthritis Influence the Gut Microbiome. Arthritis Rheumatol (2019) 71(10):1642-50. doi: 10.1002/art.40917

106. Adamopoulos IE, Suzuki E, Chao CC, Gorman D, Adda S, Maverakis E, et al. Il-17A Gene Transfer Induces Bone Loss and Epidermal Hyperplasia Associated With Psoriatic Arthritis. Ann Rheum Dis (2015) 74(6):1284-92. doi: 10.1136/annrheumdis-2013-204782

107. Gulino GR, Van Mechelen M, Lories R. Op0272 Inflammation at Barrier Tissues Such as Skin and Gut Triggers Mild Joint Inflammation and Is Influenced by Biomechanical Stress Induced by Forced-Running. In: Annals of the Rheumatic Diseases. BMJ. (2018) 77:184-185. Available at: http://ard. bmj.com/.
108. Gracey E, Hromadová D, Lim M, Qaiyum Z, Zeng M, Yao Y, et al. TYK2 Inhibition Reduces Type 3 Immunity and Modifies Disease Progression in Murine Spondyloarthritis. J Clin Invest (2020) 130(4):1863-78. doi: 10.1172/ JCI126567

109. Chen S, Paveley R, Kraal L, Sritharan L, Stevens E, Dedi N, et al. Selective Targeting of PI3K $\delta$ Suppresses Human IL-17-Producing T Cells and InnateLike Lymphocytes and may be Therapeutic for IL-17-Mediated Diseases. J Autoimmun (2020) 111:102435. doi: 10.1016/j.jaut.2020.102435

110. Chen S, van Tok MN, Knaup VL, Kraal L, Pots D, Bartels L, et al. Mtor Blockade by Rapamycin in Spondyloarthritis: Impact on Inflammation and New Bone Formation In Vitro and In Vivo. Front Immunol (2020) 10:2344. doi: 10.3389/fimmu.2019.02344

Conflict of Interest: MS: Consultancy fees/speaker fees from Abbvie, Novartis and Eli Lilly, MSD. Research support from Novartis, Eli Lilly, UCB, Janssen.

The remaining authors declare that the research was conducted in the absence of any commercial or financial relationships that could be construed as a potential conflict of interest.

Copyright (c) 2021 Mandour, Chen and van de Sande. This is an open-access article distributed under the terms of the Creative Commons Attribution License (CC BY). The use, distribution or reproduction in other forums is permitted, provided the original author(s) and the copyright owner(s) are credited and that the original publication in this journal is cited, in accordance with accepted academic practice. No use, distribution or reproduction is permitted which does not comply with these terms. 